\title{
Construction Research Fundamentals Course to Support Graduate Student Built Environment Thesis and Dissertation Research and Writing
}

\section{Mr. Mark Shaurette, Purdue University, West Lafayette}

Mark Shaurette has a MS in Civil Engineering from the Massachusetts Institute of Technology and a $\mathrm{PhD}$ in Technology from Purdue University. He is currently an associate professor at Purdue University, was a 2012 Fulbright Scholar in Ireland, and has work experience that includes 30+ years of senior construction management practice as well as work as a research engineer for the National Association of Home Builders Research Foundation. He is active in research, education, and community outreach in the areas of building retrofit for energy conservation, sustainable construction practices, management of the demolition process, material reuse and recycling, as well as instructional design in technology education. 


\title{
Construction Research Fundamentals Course to Support Graduate Student Built Environment Thesis and Dissertation Research and Writing
}

\begin{abstract}
Construction Management (CM) programs are increasingly awarding graduate degrees. Many of these university programs require some combination of standardized classroom teaching and independent research as part of the graduate level plan of study. Unlike traditional engineering degrees which test theory from a quantitative or positivist position, CM programs often relate to issues that are more difficult to measure using strictly quantifiable metrics. Because the managerial issues faced by CM graduates deal with human interaction and behavior, research in the built environment often resembles social science research to a greater degree than traditional scientific research. As graduate programs in CM expand, students need opportunities to gain experience with a range of research methodologies that are available to complete valid research on construction management issues. Previous research indicated that educators active in graduate education for the built environment support the idea that student should experience and learn about the general overarching fundamentals of research applicable to a diversity of challenges in the built environment ${ }^{1}$. Small programs can rely on the individual mentorship of students or on student opportunities to serve as research assistants, but as student populations grow, a more formalized approach is needed to support education in a variety of research methodologies as graduate students complete their thesis or dissertation obligations. This paper describes the experience of a CM program at a large Midwest research university during the first four years of a course in 'Construction Research Fundamentals' created to support student thesis and dissertation research and writing across a variety of technical, managerial, and social research on the creation or operation of the built environment. This case material will be useful for others wishing to increase the understanding of fundamentals of research appropriate for graduate research in construction related programs.
\end{abstract}

\section{Introduction}

The MS in Building Construction Management (BCM) is a department administered MS program within the Purdue University Graduate School. It offers both a thesis based on-campus MS program as well as a non-thesis distance delivery option. Although some universities offer non-thesis graduate options, thesis research is a significant component of the graduate education provided by many construction management programs. The Purdue University on-campus CM graduate program has for the last six years been offered as a thesis only opportunity. The decision to maintain a thesis only option was based on a number of factors. Some graduate faculty considered research to be an effective approach to the promotion of self-education, lifelong-learning, and development of applied fact-based problem solving skills. The decision to require a thesis followed the argument that non-thesis graduate degrees don't adequately provide the preparation for rigorous, applied problem solving in the industry setting ${ }^{2}$. Others saw the inclusion of a thesis as a way to maintain a research focus to support students who will become future CM educators. 
Growth in graduate enrollment has been occurring for the last decade and the shift to a required thesis for every graduate student completing the degree on campus created some challenges for a program that for most if its 40 plus years of existence was concentrated primarily on undergraduate education. Some of the MS growth challenge came from struggles that students often have in formulating targeted questions and/or hypotheses about construction management problems, selecting appropriate methodologies to answer the research question or test the hypotheses, as well as difficulties experienced from the poor preparation of incoming students for academic writing. Writing courses based on the Effective Army Writing program which were added to enhance student success and the initial indications of success in improving MS students' writing skills for both the on-campus thesis and non-thesis distance delivery students has been described in a previous publication ${ }^{3}$.

This paper is organized to explain the specific changes made to address the challenges resulting from limited student research skill experienced in the relatively new BCM MS program. The first section describes program structure and research challenges of the program. The balance of the paper deals with a specific course that has been pivotal in improving thesis quality. Included are a review of the literature on the subject of research fundamental preparation for CM students. This material should be helpful for others working to improve CM graduate student success.

\section{Thesis Research Preparation Challenges Experienced}

As previously mentioned, the department has over the years produced thousands of undergraduates who built successful careers in the construction industry. A graduate program had existed in the college for many years with a CM area of specialization, graduating only one or two students a year. The approval of a department administered MS in Building Construction Management in 2011 eventually grew to a graduate student enrollment of approximately 40 students in addition to the over 400 undergraduates in the department.

As is common in much of construction management higher education, faculty in the program have significant industry experience with less emphasis on research-based graduate degree experience. Many faculty have graduate degrees that did not require completion of a thesis or dissertation. As a result, those that had a research education or background were chairing an increasing number of graduate committees and were unable to provide detailed guidance for each individual student due to their workload. Also common to CM programs, limited funded construction research was completed by the department, providing very few opportunities for students to gain research experience by working alongside a faculty researcher.

An added challenge was the fact that most of the graduate student enrollment was interested in entering the construction industry after graduation and desired research which was relevant to construction industry practice. Much of the research they were interested in required a widely varied set of research methodologies that are more common to social science research than the engineering research that many of the faculty had experienced in their education. 


\section{Literature Review of Research in Graduate Level CM Programs}

Gumport ${ }^{4}$ traced the role of research in graduate education during the last century as part of a book titled "The Research Foundations of Graduate Education: Germany, Britain, France, United States, and Japan". He note that beginning in the late 1800 s, research and graduate education became closely linked at major universities primarily through the growth in the disciplines of science and engineering. The common practice of graduate student education in the US at that time consisted of a period of class-based study followed by research. Graduate education during the century that followed evolved to become a mentor based learning environment where students worked alongside professors on research projects. The benefit of this mentor-based process was that students would transition from consumers of research to producers of research. This process was accelerated in the post-World War II period where the economic expansion and cold war competition of the time period encouraged significant financial support for research. By the 1970s top tier universities had interwoven organized research and graduate education and lower tiered institutions strove to emulate this practice.

As US Federal research funds began to diminish in the 1970s and 1980s, reduced financial support for graduate students impacted the student-faculty mentor relationship by limiting the degree to which faculty could work directly with students in the research setting. The relationship began to evolve into one where the students worked more independently, often on research that the faculty mentor was not involved with. This reduced integration of graduate education and organized research activity occurred at the same time that professional graduate education began to emerge. Professional graduate education, which was intended to provide a more market-driven practitioner rather than a researcher, reduced the need for graduate research experiences $^{5}$.

Many of the traditionally research oriented disciplines in engineering and the applied sciences have an option for a non-thesis MS degree. A common non-thesis alternative to a course-only MS degree is provided through the use of a directed project rather than a thesis. The directed project is less formal than a thesis with the objective to engage the student in an industry based study culminating in a report. The topic is generally more practical than a thesis and is expected to be completed in one semester ${ }^{6}$. Some educators have questioned the validity of course-only and non-thesis graduate education even in applied engineering technology graduate programs. Grubbs and Kozak ${ }^{2}$ cite the fact that without a thesis, students do not support growth of the body of knowledge in a discipline or even focus on applied solutions to problems in the workplace. Placed into question is what value is added in a non-thesis graduate degree beyond what is learned as an undergraduate.

\section{Evolving Construction Research Philosophy}

Quantitative or positivist views of construction research dominated early construction research published in academic literature. Possible explanations for this include the fact that many construction educators came from backgrounds in engineering where quantitative research is utilized both because of its ability to demonstrate scientific rigor and validity as well as the relative ease of relating engineering theories to mathematical analysis. During the last few decades an evolution in thinking about research philosophy in construction research has come about. In 1997 Seymour, Crook and Rooke called for a debate on the role of theory in 
construction management research. Seymour et al. encouraged a dialogue about the need for a broader view of alternate research paradigms. They contended that the management components of construction require a more interpretive view of research that necessitated a reconsideration of what defined theory, rigor, and objectivity in construction research ${ }^{7}$. Later that year Runeson responded to the call for debate by stating that positivist research is the best insurance against bad research. Although Runeson acknowledged that interpretive research has a place in normative research, he asserted that it should not be taken as science. His arguments placed a clear demarcation between the value of qualitative and quantitative approaches ${ }^{8}$.

The following year Wing, Raftery and Walker provided a less dichotomous response to the debate contending that the research philosophy or methodology chosen for construction research should be based on the nature of the problem being examined. In arguing against a single research approach they pointed out that behavioral scientists had been expressing dissatisfaction with 'scientific' methods since the 1960s. Wing et al. provided numerous references from a variety of disciplines to advocate for pluralism and diversity in construction research philosophy and methodology. They suggested the complementary use of quantitative and qualitative approaches $^{9}$. It is interesting to note that the qualitative vs. quantitative debate has also been active in more recent years among researchers in engineering education ${ }^{10}$. In the construction management research community in the UK and Ireland discourse around methodological approaches have also begun to receive attention ${ }^{12}$.

\section{Research Methodologies Appropriate for CM Research}

When a theory or hypothesis fits available data or realities of data acquisition, experimental approaches to construction research are preferable because of the ability to produce generalizable results. Frequently these experimental approaches require the researcher to separate naturally occurring phenomena into small components that facilitate data collection. In 2010, Bernold and Lee describe five methods of experimental or quasi-experimental design commonly used for construction research ${ }^{13}$. These five methods; pilot testing of devices and methods, passive observation, controlled experiments, randomized experiments, or four group experiments may be favored when measurement of well-defined variables can be obtained. Unfortunately, conditions that allow such measurable evidence to be collected are often confounded by conditions beyond the researcher's control.

To overcome the challenges of experimental design, alternative philosophies and methodologies have been adapted from research more common to social science. A complete description of the range of research methods at the construction researcher's disposal is beyond the scope of this paper. However, a recent issue of the Journal of Construction Engineering and Management contains several articles describing both experimental and alternative approaches to construction research that can serve as useful reference material. Table 1 lists the range of methodologies and approaches described. While this list is by no means exhaustive it does show the breadth of research tools with which graduate students should be exposed in their education.

In addition to an introduction to multiple methodologies, students need to understand the limitations inherent in each. Because validation of research results is necessary in order to obtain true meaning or application of the research, learning differing methods of validation is also important in preparation for the execution of scholarly work ${ }^{21}$. For example multiple cycles of testing may be utilized to validate action research results ${ }^{22}$, but this approach is not necessarily appropriate or possible with other methods. Without implementation of sound and appropriate 
methodological procedures at every research step from conceptualization through data analysis and conclusions, theories and hypotheses cannot be reliably confirmed or denied ${ }^{14}$.

Table 1: Research Methods in Journal of Construction Engineering and Management Research Method Authors

\begin{tabular}{ll}
\hline Experimental Research & Bernold \& Lee $^{13}$ \\
Mixed Method Research & Abowitz \& Toole ${ }^{14}$ \\
Contextualist Research & Green, Kao, \& Larsen ${ }^{15}$ \\
Observational Research & Leicht, Hunter, Saluja \& Messner ${ }^{16}$ \\
Delphi Method & Hallowell \& Gambatese ${ }^{17}$ \\
Ethnographic Theory-Building Research & Phelps \& Horman ${ }^{18}$ \\
Action Research & Azhar, Ahmad \& Sein ${ }^{19}$ \\
Charrettes as a Research Method & Gibson Jr. \& Whittington ${ }^{20}$ \\
\hline
\end{tabular}

\section{Program Changes in the MS Degree Requirements}

The Department of Building Construction Management Graduate Committee examined the situation in search of changes that might increase the program's academic rigor in thesis production. The first decisions necessary were to examine the college MS Handbook to determine which course requirement policies, previously used when the MS with a CM area of specialization was administered at the college level, should be continued with the department level MS. The most significant decisions in this regard concerned course requirements to support thesis research. The college requirements included a three credit statistics course and a three credit course in Analysis of Research in Industry and Technology.

Although most of the departments in the college continued to utilize these requirements when they took over the administrate role for the MS area of specialization for their department, the $\mathrm{CM}$ graduate faculty determined that additional research preparation was needed. The statistics preparation was considered adequate because the university statistics department offers a consulting service available to all students to provide assistance in statistical analysis of their research. Nevertheless, other research preparation shortcomings were noted. Most significantly, although the Analysis of Research in Industry and Technology course (TECH 646) provided good general guidance on research design, procedures, and writing, it offered little in the way of introduction to research specifically oriented toward construction. It also offered little in the way of practice research activity and critical review of writing to support the academic writing preparation that incoming students needed.

The initial change made to address these shortcomings was the addition of two writing courses of one credit each and a one credit Research Seminar course for a total of three additional research and writing support credits. While the writing courses proved to provide valuable practice and opportunity for feedback ${ }^{3}$, the Research Seminar was not fulfilling the need for a broader view of $\mathrm{CM}$ research. The Research Seminar was patterned after the common practice of many departments on campus of inviting faculty and advance graduate students to make a presentation 
and lead a discussion about their ongoing research. This proved to be difficult because few CM faculty had ongoing research projects, and the current graduate students were not as well prepared for their research as the graduate faculty expected.

The ultimate decision was to retain the three additional credits of coursework supporting research, but with a greater emphasis on research experience. All MS students would be required in their first semester to take the one credit Academic Writing I writing course plus the Research Seminar. The Research Seminar would shift to an introduction to a wide variety of research methodologies that are used by construction researchers. Presentations made by research active faculty would be included in the Research Seminar when possible. This course helped students begin thinking about thesis research beginning in their first semester. The third credit would come in the second semester with the one credit Construction Research Fundaments course that is the subject of this paper. The second writing course was made optional. Requiring the additional writing course would have required all students to add three credits to their plan of study to meet the MS course credit requirement of 33 because one, two, and four credit courses are not very common. Some students take the optional course after recognizing their writing weakness in the first writing course, but most students have been successful with the help of the progressively more challenging practice, guiding, and coaching in the Academic Writing I writing course.

\section{The Construction Research Fundamentals Course}

During the spring semester of 2013 the Purdue University Department of Building Construction Management (BCM) introduced a MS course in Construction Research Fundamentals. The primary motivation for creation of the Construction Research Fundamentals course was the limited opportunity MS students have to experience or observe the design and execution of CM research. In addition, our decision to allow MS students to select their own major professor and thesis committee has contributed to a lack of faculty mentoring during the early semesters of the students' thesis proposal development. These two factors combined with a desire to help students connect construction process based research objectives to real-word CM problems while practicing their oral and written communication skills in a low risk setting provided the following course objectives.

Upon completion of Construction Research Fundamentals, students are expected to:

- Constructively critique the research of others.

- Effectively seek clarification or critique for some components of their thesis research framework or methodology.

- Complete and defend a proposal framework for their thesis research.

The experiences and lessons learned in recent work of others in research course development ${ }^{23,24,25,26}$ was utilized in building a lesson plan to support these objectives. The concepts of: (1) small exercises as a mentoring experience during each class to guide students to explore and reflect ${ }^{24}$; (2) peer group mentoring; and (3) a strong emphasis on learning by doing in place of lecture ${ }^{25,26}$, prompted the choice to restrict time devoted to lecture to 10 minutes or less of every class meeting with the balance of time spent on discussion or peer group activities. Development of skills needed to adequately explore and support a topic using existing literature, 
develop a well-crafted research question, and design a clear research framework were also $\operatorname{added}^{27}$.

The students are encouraged to take the required three credit technology research course (TECH 646) offered by the college during the same semester as Construction Research Fundamentals. TECH 646 prepares students to write and research using a standard university thesis format with an introduction to a variety of methodologies used in technology research. The group mentoring and peer reflection of the Construction Research Fundamentals course complements and supports the mostly lecture activities of the college research course. Table 2 shows the basic outline of the Construction Research Fundamentals schedule.

\section{Table 2: Schedule for Construction Research Fundamentals}

\begin{tabular}{|c|c|c|c|}
\hline & Guiding & & \\
\hline Week & Concepts & Assignments Due & Essential Question \\
\hline 1 & $\begin{array}{l}\text { Role of Research } \\
\text { Fundamentals }\end{array}$ & & Why are you required to take this course? \\
\hline 2 & $\begin{array}{l}\text { Constr Research } \\
\text { Examples }\end{array}$ & $\begin{array}{l}\text { Students find } 2 \text { example construction } \\
\text { thesis abstracts }\end{array}$ & $\begin{array}{l}\text { In what way does research topic influence choice of } \\
\text { research philosophy, theory or methodology? }\end{array}$ \\
\hline 3 & $\begin{array}{c}\text { Literature } \\
\text { Support \& Map }\end{array}$ & $\begin{array}{l}\text { Readings, Complete Literature } \\
\text { Support table \& Map for topic }\end{array}$ & $\begin{array}{l}\text { What is the purpose of a literature review and what } \\
\text { must it contain? }\end{array}$ \\
\hline 4 & $\begin{array}{l}\text { Topic Devel. \& } \\
\text { Ethics }\end{array}$ & $\begin{array}{l}\text { Readings. Fine tune literature map, } \\
\text { identify research discipline or genre }\end{array}$ & $\begin{array}{l}\text { What possible research structure(s) \& ethical issues } \\
\text { should be consider for your thesis topic? }\end{array}$ \\
\hline 5 & $\begin{array}{l}\text { Philosophy \& } \\
\text { Methodologies }\end{array}$ & $\begin{array}{l}\text { K \& R Ch. } 1 \text { \& 7, Bring journal article } \\
\text { with methodology you might use }\end{array}$ & $\begin{array}{l}\text { How do research philosophy, scientific theory \& } \\
\text { methodology impact research outcome? }\end{array}$ \\
\hline 6 & $\begin{array}{l}\text { Research } \\
\text { Question }\end{array}$ & $\begin{array}{c}\text { Develop research question or } \\
\text { hypothesis. Update system diagram. }\end{array}$ & $\begin{array}{l}\text { What are the characteristics of a good research } \\
\text { question or hypothesis? }\end{array}$ \\
\hline 7 & Survey Research & $\begin{array}{c}\text { K\&R Ch. } 11 \text {, posted reading. Develop } 3 \\
\text { construction survey questions. }\end{array}$ & When is using a survey appropriate? \\
\hline 8 & Case Studies & $\begin{array}{l}\text { Ch. } 9-K \& R \text { and Blackboard Readings. } \\
\text { Be prepared to discuss sample cases. }\end{array}$ & $\begin{array}{l}\text { What separates an informative case study from a } \\
\text { research case study? }\end{array}$ \\
\hline 9 & $\begin{array}{l}\text { Interviews } \\
\text { Concept Paper }\end{array}$ & $\begin{array}{l}\text { Read Knight \& Ruddock Ch. } 10 \\
\text { Research Concept Paper Due }\end{array}$ & $\begin{array}{c}\text { What preparation is critical to prepare for interview } \\
\text { research? }\end{array}$ \\
\hline 10 & $\begin{array}{l}\text { Validity \& } \\
\text { Reliability }\end{array}$ & Readings on Blackboard & $\begin{array}{l}\text { What can be done to seek a valid research design } \\
\text { that can be reliably implemented? }\end{array}$ \\
\hline 11 & $\begin{array}{l}\text { Communicating } \\
\text { Framework }\end{array}$ & $\begin{array}{l}\text { Prepare a very rough sketch of your } \\
\text { proposed thesis research process. }\end{array}$ & $\begin{array}{l}\text { How can you clearly communicate your research } \\
\text { process? }\end{array}$ \\
\hline 12 & $\begin{array}{l}\text { Experimental } \\
\text { Approaches }\end{array}$ & Readings on Blackboard & $\begin{array}{l}\text { When can experimental research designs be used to } \\
\text { complete } \mathrm{CM} \text { research? }\end{array}$ \\
\hline 13 & Data Analysis & Readings on Blackboard & $\begin{array}{l}\text { What are common data analysis approaches and } \\
\text { available resources for } \mathrm{CM} \text { research? }\end{array}$ \\
\hline 14 & $\begin{array}{l}\text { Lit. Support for } \\
\text { Methodology }\end{array}$ & $\begin{array}{l}\text { K\&R Ch. } 12,13 \text {. Critique } 3 \text { articles } \\
\text { using research similar to your thesis. }\end{array}$ & $\begin{array}{c}\text { Why do you need to have literature support for your } \\
\text { research methodology? }\end{array}$ \\
\hline 15 & $\begin{array}{l}\text { Describing Your } \\
\text { Research }\end{array}$ & $\underline{\text { Three Minute Proposal Presentations }}$ & \\
\hline
\end{tabular}


Each weekly meeting of the course is based around a guiding concept and essential question. In addition to the essential question shown in Table 2, topical sub-questions are also used to provide additional discussion points. These two weekly ideas help the instructor introduce the class discussion and provide structure for the students to reflect on the experiences of the week's activities as a way to reinforce the learning that has taken place and to identify additional areas that they need to explore in preparation for their thesis research.

Three or four times during the semester other instructors are asked to fill in or co-facilitate the class discussion. This is helpful to leave the primary instructor's schedule open for conflicts that come from conference attendance or other obligations. This also helps introduce the students to a variety of graduate faculty.

\section{Textbooks, Assignments, and Activities}

As shown in Table 2, the course includes readings supplied by the instructor in addition to assignments that encourage students to identify, read, and critique literature which might be helpful as source material for their thesis research. Readings supplied by the instructor include many taken from the course textbook ${ }^{28}$, journal papers providing examples of, or instruction on, use of various methodologies in CM research. Suggested readings that introduce students to the challenges of the thesis or dissertation writing process, presented by individuals who have successfully navigated those challenges ${ }^{29,30}$, are also provided.

Details of each assignment and in-class activity in the course are beyond the scope of the paper. Nevertheless, several are worth mentioning due to the anecdotal evidence of their usefulness or enthusiastic response from the students. The first activity that has proven useful is the use of a $\mathrm{PhD}$ student or advanced MS student to visit the class in week 2. During this class the students get to see an example of the research that is being conducted by current students. The discussion that follows helps them to explore the challenges that other students encounter during their research work as well as the solutions that were used by the presenting student to move forward.

The activity which students enjoy the most is called the 'Candy Game'. The author was first introduced to this activity during a 2011 ASEE presentation ${ }^{23}$. The basic idea of the game, introduced in week 6 , is to provide students with a fun opportunity to think about research design without being encumbered by the need to connect it directly to their thesis topic. The primary research related component of the game is development of a clear research question or hypothesis by supplying a multidisciplinary context for a research question. The context typically used is supplied by a bag of candy. A bag of candy (usually M\&Ms) is supplied to each group of students with the basic instructions "After 15 minutes of discussion in groups of two about some research study that could be conducted on or about this bag of candy, be prepared to tell us your specific research question and the basic procedures you would use to answer the question". Other approaches giving student more choice (selecting from different types of candy) and different contexts (an assortment of common trinkets with various corporate logos given away as marketing) was tried but proved to be less useful in promoting full class discussion due to the fact that not everyone worked on the same item or research context.

An assignment with follow-up class discussion that has proven to be very helpful is the use of concept maps for students to dissect the many interrelated parts of their topic of interest and to 
identify a variety of literature areas that could be useful to support their knowledge about the subject. A web resource that explains the use of system diagrams and concept maps ${ }^{31}$ is introduced to prepare students to use concept maps as a tool for examining their research topic area more fully. Students are asked to initially create the concept map diagram early in the semester (week 3) and to continually update (or start over) as they discover the complexities of their area of interest. We review and discuss many of the student diagrams throughout the semester. This activity and discussion has been most valuable in demonstrating the need for: (1) narrowing of the scope of their research; (2) developing very specific research questions; and (3) the many interrelated subjects (and disciplines) impacted by their area of research interest. As an added benefit, some students begin to see the value of using a diagram to communicate their ideas as well as the iterative process necessary to proceed from research interest to well defined research.

\section{Course Deliverables}

Students are expected to prepare for every class meeting by completing the reading and weekly assignments. Because class discussion is often tied to specifics of the students' assigned work or specific interests, they are asked to submit the written assignments the night before class so that the instructor can prepare for the discussion that week. These weekly assignments are not graded on content because their primary purpose is to move students forward in building a thesis research framework that can be completed in a timely fashion. Discussion and activities for each week are often targeted to the issues and questions that come from the students in previous weeks. To encourage risk-taking as they propose multiple research questions and/or research frameworks for discussion, grades are largely based on regular and timely discussion. It is the author's experience that students who are intrinsically motivated to complete high quality thesis research don't need grade inducements to take the course seriously. Most students recognize the formative benefits of the activities and prepare well for them. Second year MS students reinforce the need to take the Construction Research Fundamentals activities seriously and student engagement in the course has improved each year since the course was first introduced.

Two graded course deliverables are completed by the students. Each was selected to support the students' thesis research journey. The first is the submission of a short Research Concept Paper. Less detailed than the first three chapters of the thesis that is typically submitted as a full research proposal prior to beginning their thesis research, the concept paper is a simple unstructured format that students find less daunting to produce than the full proposal. It is due at mid-semester and consists of three to five pages of text that must include: (1) some description of the general area of study that interests them; (2) a brief literature supported synthesis of what is known and not known about the subject; (3) the purpose of their study; (4) their research question(s) or hypothesis; (5) the research methodology(s) they intend to use to answer the research question(s) or validate the hypothesis; and (5) their preliminary plan of study to show how their course selection will support their thesis research. This simple proposal forces students to focus their research framework in a format that is helpful in discussing their research ideas with others, prior to investing significant time in the full proposal. The timing of the Research Concept Paper, completed early in their second semester of study, helps to provide information that can be used to initiate discussion with potential thesis committee members. In addition, the time commitment is small enough that they can feel greater freedom to shift to other possible areas of research if necessary. 
The course concludes with a requirement that all students prepare and present a Three Minute Thesis (3MT). The original 3MT ${ }^{\circledR}$ (http://threeminutethesis.org/about-3mt) was developed by the University of Queensland to cultivate and celebrate students' academic presentation and research communication skills. It has since been adopted by universities around the world as a competition requiring students to effectively explain their research in three minutes. Many interesting and entertaining 3MT competition presentation videos are available through a simple web search. The opportunity for students in the Construction Research Fundamentals course to practice their presentation skills in a low-risk setting for peers with whom they have been interacting regularly throughout the semester has been useful in reducing the stress level that students often feel when ultimately presenting the oral defense of their research proposal to their thesis committee. In addition, students begin to see that the ability to summarize their research in a concise presentation is valuable in communicating with their committee or others who inquire about their research.

\section{Course Evaluation and Outcomes to Date}

Course evaluations, completed by the students at the conclusion of each of the four years Construction Research Fundamentals has been offered, indicate a very positive view of the course. The overall rating of the course by students on the electronic evaluation system, using a five point scale ( 5 - excellent, 1 - very poor), yielded a $4.7-5.0$ rating each year with an 80$90 \%$ response rate. Ratings on the balance of the evaluation questions were equally positive.

Written student comments and suggestions in the evaluation were common and followed several themes. Some example themes and an example quote from the evaluations for each theme include:

- The course was enjoyable - "I had so much fun in this course."

- Peer discussion was helpful - "It is nice to discuss our Thesis Proposals with fellow BCM students."

- Group activities were helpful - "The group exercises that we are made to participate in the class are really helpful."

- Students liked having a variety of presenters - "I loved having the speakers who came in to give the class some variety and to help us think about our thesis in different ways."

- The course was a good complement to the college research course - "It is an ideal course to take the same semester as TECH 646."

- The three minute thesis presentation was well received - "The 3 minute presentation is really interesting and helps in development of presentation skills."

The evaluation question that rated whether "The course requires more time and effort than others at this level" did have a few outliers. The outliers felt the course did indeed require more time and effort. Nevertheless most students accepted the work load as no more time consuming than other classes, but desired more class time for discussion and peer interaction. Some evaluation quotes that demonstrate this view are:

- "The course should be extended to 2 hours ... I believe it would help provide more time for student interaction and brainstorming." 
- "One hour class duration was not enough to discuss every participant's idea and the assignments. It is probably the only class where we discuss our research topics and can get a feedback to know if we are approaching the problem the right way."

Admittedly, the small enrollment of approximately 10 students per semester and other graduate program enhancements introduced in recent years, such as the addition of a required academic writing course, and the growing experience in mentoring students by our graduate faculty, limit the ability to make sweeping claims about the outcomes of the Construction Research Fundamentals course. Nevertheless, we suspect one significant program outcome has been influenced, at least in part, by the course. Timely completion of thesis based MS degrees has improved. Students completing the MS thesis within two years of first enrollment are now the norm for on-campus MS students.

\section{Future Plans for the Construction Research Fundamentals Course}

Due to the course popularity and suggestions from students who have completed the course, the Construction Research Fundamentals course will likely be increased to two credit hours. TECH 646 , the research support course for the entire college, has been the primary resource for both $\mathrm{MS}$ and $\mathrm{PhD}$ students. Because $\mathrm{PhD}$ enrollments have been rising, a new two credit course specifically targeting MS students (TECH 546) will be introduced in place of the three credit TECH 646 which will be targeted to PhD students. This change will make an additional one credit available to devote to construction specific research.

Another future goal of the MS program is increased publication of thesis research. All MS students are required to submit an article for publication prior to graduation. Some students are successful in actually publishing their work, but most do not devote adequate time to the article preparation and have their work rejected or fail to follow through after graduation with the required revisions needed to reach publication. Because more students are successful in conference publication of partial results prior to completing their thesis or research unrelated to their thesis, the lack of published articles derivative of their thesis research may simply be based on the end of degree timing of submitted articles and distraction from other priorities after graduation. It is our hope that as the quality of thesis research continues to improve, we can expect the rate of publication to increase as well.

\section{Conclusion}

As this program continues, it will be necessary to continually assess the impact of both the MS thesis research and writing instruction. Even though there is some early evidence of success, the sample size is small. Still, there is ample evidence to continue offering the Construction Research Fundamentals course and based on student input, to expanding the time and credit dedicated to the course.

\section{Bibliography}

1. Scott, L. and Shaurette, M. (2012). Toward an Understanding of Research Fundamentals to Support Graduate Education in the Built Environment. CIB International Conference on Management of Construction: Research to Practice. Montreal, Canada. 12 pages, 294-306. 
2. Grubbs Jr., A.B. and Kozak, M.R. (2000) Engineering technology masters program: thesis required! Proceedings of the American Society for Engineering Education, 2000 Annual Conference \& Exposition. Session 3247.

3. Rapp, R. and Shaurette, M. (2014). Overcoming the Writing Challenges of Students in a Distance Delivery Technology Master of Science Program. Proceedings of the American Society for Engineering Education, 2014 Annual Conference \& Exposition, Indianapolis, IN.

4. Gumport, P.J. (1993a) Graduate education and organized research in the United States. In Cark, B.R. (Ed.) The Research Foundations of Graduate Education: Germany, Britain, France, United States, Japan. (pp. 225-260). Berkeley, CA: University of California Press.

5. Gumport, P.J. (1993b) Graduate education and research imperatives: views from American campuses. In Cark, B.R. (Ed.) The Research Foundations of Graduate Education: Germany, Britain, France, United States, Japan. (pp. 261-293). Berkeley, CA: University of California Press.

6. Hartman, N., Sarapin, M., Bertoline G. and Sarapin, S. (2009) Examining the nature of technology graduate education. The Journal of Technology Studies. 35(1). 76-82.

7. Seymour, D., Crook, D. and Rooke, J. (1997) The role of theory in construction management: a call for debate. Construction Management and Economics. 15, 117-119.

8. Runeson, G. (1997): The role of theory in construction management research: comment. Construction Management and Economics. 15:3, 299-302.

9. Wing, C.K., Raftery, J. and Walker, A. (1998) The baby and the bathwater: research methods in construction management. Construction Management and Economics. 16:1, 99-104.

10. Borrego, M., Streveler, R.A., Miller, R.L. and Smith, K.A. (2008) A new paradigm for a new field: Communicating representations of engineering education research. Journal of Engineering Education. 97 (2): 14762.

11. Borrego, M., Douglas, E.P. and Amelink, C.T. (2009) Quantitative, qualitative, and mixed research methods in engineering education. Journal of Engineering Education. 98 (1), 53-66.

12. Dainty, A. (2008) Methodological pluralism in construction management research in Knight, A. and Ruddock, L. Advanced Research Methods in the Built Environment. United Kingdom: Wiley-Blackwell.

13. Bernold, L.E. and Lee, T.S. (2010) Experimental research in construction. Journal of Construction Engineering and Management. 136 (1), 26-35.

14. Abowitz, D.A. and Toole, T.M. (2010) Mixed method research: fundamental issues of design, validity, and reliability in construction research. Journal of Construction Engineering and Management. 136 (1), 108-116.

15. Green, S.D., Kao, C.C. and Larsen, G.D. (2010) Contextualist research: iterating between methods while following an empirically grounded approach. Journal of Construction Engineering and Management. 136 (1), 117126.

16. Leicht, R.M., Hunter, S.T., Saluja, C. and Messner, J.I. (2010) Implementing observational research methods to study team performance in construction management. Journal of Construction Engineering and Management. 136 (1), 76-86.

17. Hallowell, M.R. and Gambatese, J.A. (2010) Qualitative research: application of the Delphi method to CEM research. Journal of Construction Engineering and Management. 136 (1), 99-107. 
18. Phelps, A.F. and Horman, M.J. (2010) Ethnographic theory-building research in construction. Journal of Construction Engineering and Management. 136 (1), 58-65.

19. Azhar, S., Ahmad, I. and Sein, M.K. (2010) Action research as a proactive research method for construction engineering and management. Journal of Construction Engineering and Management. 136 (1), 87-98.

20. Gibson Jr., G.E. and Whittington, D.A. (2010) Charrettes as a method for engaging industry in best practices research. Journal of Construction Engineering and Management. 136 (1), 66-75.

21. Lucko, G. and Rojas, E.M. (2010) Research validation: challenges and opportunities in the construction domain. Journal of Construction Engineering and Management. 136 (1), 127-135.

22. Shaurette, M. (2009) Using action research to refine demolition curriculum for construction management students. Associated Schools of Construction, International Proceedings of the 45th Annual Conference, Gainesville, FL.

23. Landis, A.E., Bilec, M.M., Klotz, 1., and Pearce, A.R. (2011) Lessons Learned From A Distance Learning Research Methods Course Co-Taught By Clemson, University Of Pittsburgh, And Virginia Tech. Proceedings of the American Society for Engineering Education, 2011 Annual Conference \& Exposition. Session 2148.

24. Hartmann, A., Dorée, A. and Martin, L. (2010) A Constructivist Approach for Teaching Research Methodology in Construction Management, International Journal of Construction Education and Research, 6:4, 253-270. http://dx.doi.org/10.1080/15578771.2010.527181

25. Kresta, S.M., Nychka, J.A., and Graves, R. (2011) Writing Well: Building Traction And Triumph Into CoAuthorship. Proceedings of the American Society for Engineering Education, 2011 Annual Conference \& Exposition. Session 1164.

26. Freeman, S., Eddy, S.L., McDonough, M., Smith, M.K., Okoroafor, N., Jordt, H., and Wenderoth, M.P. (2014) Active learning increases student performance in science, engineering, and mathematics. Proceedings of the National Academy of Sciences of the United States, 111:23, 8410-8415. http://doi.org/10.1073/pnas.1319030111

27. Parker, R. (2012) Skill Development in Graduate Education. Molecular Cell, 46, 377-381. DOI 10.1016/j.molcel.2012.05.003

28. Knight, A. (ed.) and Ruddock, L. (ed.) (2008) Advanced Research Methods in the Built Environment. New Jersey: Wiley-Blackwell. ISBN 978-1-4051-6110-7

29. Roberts, Carol M. (2010). The Dissertation Journey: a practical and comprehensive guide to planning, writing and defending your dissertation (2nd ed.). Thousand Oaks, CA: Corwin. ISBN 978-1-4129-7798-2

30. Levine, S.J. (ND) Writing and Presenting Your Thesis or Dissertation. www.learnerassociates.net/dissthes

31. (ND) ICRA Learning Resources - Systems Diagrams Guidelines. Retrieved January 10, 2017 from http://www.sswm.info/sites/default/files/reference_attachments/HAWKINS\%20ny\%20System\%20Diagram\%20Gui delines.pdf 